\title{
Bandung Local Resident Perception of Asia Africa Conference Carnival 2015
}

\author{
Authors: Hanif A. Rachman, Indri Desty, Indriana \\ Permatasari, R. Firman Ardiansyah, Rahmania Dirza, \\ Yogi Haris Prayogo \\ fagusjr@gmail.com indriyusniar@gmail.com \\ permataindriana@gmail.com fhier.ardiansyah@gmail.com \\ rahmaniadazizah@yahoo.com \\ yogiharisprayogo@gmail.com
}

\begin{abstract}
It can be interpreted that the mega event had a variety of impacts, both positive and negative in the community (local communities) and relevant stakeholders (Bowdin at.al 2006) with the statement that the mega event will bring a positive and negative effect on the economy, tourism, physical, cultural, psychology and politics. But the impact is fairly common. Ritchie (1984). From the results of previous studies, there are five dimensions positive impact on society of Shanghai, among others city image enhancement and consolidation, the development of tourism infrastructure, increase economic benefits, cultural exchanges and the emergence of environmental and cultural preservation. As well as their three-dimensional negative impacts, such as increased costs of the economic, social and environmental issues, as well as cultural conflict, (Yang, Zeng, and Gu (2010). Asian African Carnival 2015 is a Mega Event that involve several countries from all over Asia and Africa. Like many other Mega Event, it has many discussion regarding the impact. The purpose of this research is to explore about the positive and negative impact from AAC 2015 from the local residents perspectives. The resident within this research is limited in 6 sub-districs which involved directly and feel the impact of this event. Those sub-districts are as followed : Kecamatan Coblong, Kecamatan Bojongloakaler, Kecamatan Batununggal, Kecamatan Sumur Bandung, Kecamatan Regol, dan Kecamatan Lengkong. This research uses qualitative research with descriptive research techniques, By using purposive sampling method, the respondents of this research were the opinion leader and public leader within the 6 sub districts. In this study, researchers using interview using semi structured interview along with documentation study of various national and international online media. Data were collected through conducting 38 informants which considered as opinion leader and public leader. Data was analyzed using qualitative data analysis by trying to identify the main ideas in each interviews, finding keyword and grouping of the same keyword. After that trying to compile and taking conclusions regarding one idea. The results of the research shows the 3 most positive impacts which is felt by the local residents were increasing residents pride toward the City of Bandung, Increasing Spirit of Bandung Residents and Increasing Level of Cohesion among Bandung Residents. As for the negative impacts which most delt by the local residents were environment and landscape damage, pollution, and traffic problems. It can be concluded that Asian African Carnival 2015 have been proven to have positive Impacts toward local resident. However, there will be some points that should be considered for the future Mega Events in Bandung, especially which will be held along Asia Afrika Street.
\end{abstract}

Keywords- Mega event, Impact of Mega Event, Local Resident, Residents' Perception

\author{
Authors: Indriyani Handyastuti S.I.Kom., M.Sc. Deddy \\ Adi Sudharma, S.Sos. MM. Par. \\ R. Darmawan Sundayana, S.Sos. \\ inh@stp-bandung.ac.id \\ ppk1@stp-bandung.ac.id \\ Darmawansundayana2@.gmail.com
}

\section{INTRODUCTION}

Event on a large scale, also called Mega Event is an event that is sought after by many countries because it has a wide variety of reasons one of which is to improve their country's image as a tourist destination. ( Getz, 2005 ; Hall \& Page, 2009 : 26 ). As for the notion side event is a series of supporting events that can be made on a small scale. (Getz, 2007: 25 ).

In the implementation of the mega event, many parties are involved, one of which is the local community. The response from the local community is needed. If the public response was not measured, whether negative or positive, will result in failure to achieve the development of tourism in the area , because people are reluctant to participate in such activities. (Kim \& Petrick, 2005: 26).

(Bowdin et al.,2001), "mega event have wide range of impact, both positive and negative, on host communities and stakeholders". (Yang, Zeng, and Gu (2010)), "investigated Shanghai residents perceptions of the impact of 2010 Shanghai Expo. The results of their study showed that there were five dimensions of positive impacts among the Shanghai residents, including city image enhancement and consolidation, tourism infrastructure development, economic benefits, culture exchange, and environmental and culture preservation, and three dimensions of negative impacts, such as economic cost,and culture conflicts".

Before Asian African Conference Commemoration (AACC) 2015, the first Asian-African Conference held in Bandung, which was attended by 29 state non - bloc of Asia, Africa, and the Middle East .While in Bandung, AACC 2015 has ben held. supporting events of AACC 2015 is Asian African Conference Commemoration 2015.

There are 6 series of Asian African Conference Commemorations' activities that include the Solidarity Day (Tribute to Soekarno \& Mandela), Bandung in 1955 (Photo Exhibition of 1955 Asian African Conference), Asian African Meet \& Greet (Mall to mall performance), Angklung for the World (20000 Angklung Performers), Asian African Parade (A Custom \& Percussion Street Festival), (www.asianafricancarnival.com). Local community contribution for an event was very important, ( Getz 2005) included in the KAA 2015. The problems that will be adopted by the authors is How the Perception of the Local Community Bandung against KAA, 2015?

The boundaries of this research issues to be discussed include: 
1. (Tribute to Soekarno \& Mandela ), Bandung 1955 (Photo Exhibition of 1955 Asian African Conference), Asian African Meet \& Greet ( Mall to mall performance ), Angklung for the World ( 20.000 Angklung Performers ), Asian African Parade ( A Custom \& Percussion Street Festival ).

2. Research will be limited to the local community's response Bandung in 6 ( six ) districts which became a place of execution of the six events There is District Coblong , District Bojongloakaler , District Batununggal, District Batununggal, District Sumur Bandung, District Regol, and District Lengkong .

3. Local Community Bandung is the people who are directly affected, the people who actually live in the area the event, and the people who participated directly in the KAA 2015.

4. The resource persons interviewed researchers are Organizer , Community Leaders, Cultural and Community Activist.

5. The research will be limited to six dimensions items, namely, City Enhancement and Consolidation, Tourism Infrastructure Development, Economic Benefit, Environmental and Culture Preservation, Social and Environmental Problems, Culture Conflicts.

\section{LITERATURE REVIEW}

The residents perception is measured to see the positive impact that is accepted by society, as stated Gursoy, Kim, dan Uysal (2004) mengungkapkan "Events increase pride and create cultural identity, cohesion and increased knowledge of the area, it becomes important to understand the perceptions of residents and, in doing so, to try to maximize the positive perceptions". (Kim \& Petrick, 2005:26), "If residents perceptions are not measured, a phenomenon known as the failure of support for tourism development may occur. This could imply a reluctance to work in the tourism industry and resentment towards tourists could be perceived".

(Kim \& Petrick, 2005), "For this reason, the impacts of these events need to be identified and studied from a residents point of view". (Bowdin et al.,2001), "mega event have wide range of impact, both positive and negative, on host communities and stakeholders". Ritchie (1984) developed a classification of impacts that should be assessed prior to any given mega-event. Six types of impacts were identified : economic, tourism/commercial, physical, socio-cultural, psychological, and political, each of which can have both positive and negative manifestations.

(Yang, Zeng, and Gu (2010), “investigated Shanghai residents perceptions of the impact of 2010 Shanghai Expo. The results of their study showed that there were five dimensions of positive impacts among the Shanghai residents, including city image enhancement and consolidation, tourism infrastructure development, economic benefits, culture exchange, and environmental and culture preservation, and three dimensions of negative impacts, such as economic cost,and culture conflicts". These are the theory of positive impact:

\section{City Enhancement \& Consolidation}

Silvestre, (2009), “A successful mega-event is a good advertisement for the host city and host country. With the development of technology and media broadcasting, one mega-event could attract millions of people around the world, which is a great opportunity for the city to raise its profile, acquire prestige and enhance its status."

\section{Tourism infrastructure Development}

New and renovated facilities and public spaces constructed for mega-events benefit tourists as well as the local residents. However, these facilities and venues often turn into highly commercialized venues after the events (Chalkley and Essex, 1999) and unlikely to beused by the local community.

\section{Economic Benefit}

Donald Getz - Event Studies, Theory, Research and Policy for Planned Events (Events Management) 2007 Getz and Frisby (1991) developed a framework for local government policymaking in the events sector, and their framework can be applied to event-related policy in general. Infrastructure: Provision and improvement of necessary services (roads, water, etc.) and public venues (e.g., theatres, arenas, parks, plazas).

4. Environtmental \& Culture Preservation Concerns include resultant traffic and congestion, the possibility of damage to sensitive areas, and the addition to waste and pollution. The 'greening' of events will remain a major issue, with theOlympics leading the way by implementing its own environmental program. A good example of how an event can become more environ- mentally friendly is that of the Cherry Creek Arts Festival in Denver, Colorado (pro- filed in Getz, 1997, and again in 2005).

These are the theory of negative impact :

1. Social \& Environmental Problems

Disruption of the lifestyle of residents .Sherwood (2007) refers to increases in traffic and noise and the general disruption to normal daily routines caused by the hosting of an event in the destination. Furthermore, overcrowding, congestion and noise are as cribbed to an influx of event visitors in the host destination.

\section{Culture conflict}

on the negative side, mega-events could be a disturbance to the lifestyles of local residents. Hiller (1995) proposed an intrusion-reaction model to illustrate this scenario. According to this model, when a city hosts a mega-event, the sudden influx of visitors requires detailed attention to logistics and services and the host city does not want to be embarrassed. In this case, the local residents, with no power to change the situation, have to endure the disturbance as a result of the large influx of visitors. 


\section{METHOD}

The research design used in this study is through a qualitative approach, with the technique of gathering data using interviews, documentary studies. Population researchers took data from the website of Population and Civil Registry that exist in six affected districts and districts that participate directly in the Warning KAA, 2015, there are District Coblong, District Bojongloakaler, District Batununggal, Bandung District wells, District Regol, and District Lengkong.

\section{a. Sampling}

In this study, the determination of sampling using nonprobability sampling. The technique of taking Nonprobablity Sampling of population 6 districts that are directly affected Warning KAA 2015, among other things Coblong Subdistrict, District Bojongloakaler, District Batununggal, Bandung District wells, District Regol, and District Lengkong.

Researchers interviewed the organizer as Key Member of Key Member it self authors get advice on interviewing district head, and from the district head to the headman, headman of the author interviewed youth and continued to Citizen Association such as RW, RT, as well as residents. Researchers also adjust the results of the interview organizer as supporting data reference interview. As for the informants in this study include: Chairman of (BCCF) Bandung Creative City Forum Association, Steering Committee of (AACC) Asian African Conference Commemoration, Head of a few districts such as Camat and Lurah, Youth, RT, RW and Citizens.

\section{RESULT AND DISCUSSION}

The overall research results (Table 1) show that residents perception of the positive and negative impact of the AACC emphasized the criteria of :

a) Opportunity to introduce Bandung To The World

Roche (1994) asserts that a successful Mega Event could be advertising or introduction to the host city itself, with the development of technology and media publications, Mega Event could attract the attention of millions of people worldwide. b) Improved image of Bandung in the International Scope

Roche (1994) explains that if a Mega Event is successfully implemented, then the Mega Event will create a positive image of the city or country in the host.

c) Increase of Bandungs' Residents Cohesion

Howard \& Crompton (2005) an event that is already established and successful can lead to increased psychological sense of pride and cohesion among the population and the national population.

d) Occurs community spirit

As Kim et al (2006) the city or region to host the Mega Event into must consider the impact that would be caused, as a positive social impact which can include increased community pride, quality of life, strengthen the culture and traditions that can help and build a national identity.

\section{e) Improved City Beautification}

(Silvestre, 2009), on the implementation of a Mega Event, a lot of changes, especially in improving the beauty of the city, ranging from the improvement of roads, sidewalks, as well as theme parks that ultimately increase profits to the city of Bandung.

\section{f) Improved Shopping Facilities}

In the study the authors collected documentation, there is one media bisnis.liputan6.com say that an increase in shopping facilities in the city of Bandung, from AACC 2015 .

\section{g) Increased Recreation Facilities}

In the study authors collected documentation, there are five articles in the media news.detik.com; cikalnews.com; cikalnews.com; antaranews.com; and galamedianews.com media as saying that an increase in leisure facilities in the city of Bandung. With the improvement of roads, sidewalks, park, which enhances the beauty of the city of Bandung after KAA, visitors Asia Africa rose 7 times per day.

h) Improved sanitation facilities

In the study authors collected documentation that there are 4 articles in the media muria.co; cikalnews.com; and two articles of kompasiana.com saying that given out to the public that the preparation of Bandung in the face of KAA have extended sanitation facilities for around Gedung Merdeka like the gotong - royong to clean Area community building and alerted the janitor to keep clean and the beauty of the city of Bandung. 
i) Improvement of Tourism Service Facilities

In the study authors collected documentation, according to four media (studipariwisata.com, indopos.co.id, tribunews.com, cnnindonesia.com) launch several articles that the media confirmed the increase in tourism service facilities to support the success of KAA 2015

\section{j) Development Acceleration of State Infrastructure}

Whitson and Horne on the implementation of international events will happen concentration on society itself in terms of economic, cultural and advantages for the environment such as city infrastructure, associated with keaadaan preparation for the Asian African Conference Commemoration it complies with the conditions of the ideal state.

\section{k) Increasing Employment}

Hemphill et al (2004) delivered some very encouraging sustainable economic events through the provision of skills in supporting the local community. Then from the web (2001) volunteers are very helpful in an event and socially sustainable, but making these volunteers can not only focus to local communities and to take volunteers must be skilled.

\section{1) Improvements Economic Conditions}

(Dwyer et al, 2000;. Hoexter, 2006; Stern, 2006) mentions as host a Mega Event will have an impact on the local economy is supported by Getz (1997) in the Mega Event will be concerned with the local authorities of the benefits of the Mega Event in a city will enhance the economic asset for the local community.

m) Growth Acceleration Bandung

DeSimone and Popoff (1997) suggests the influence of sustainable management will emerge from the growing demand influenced by the surrounding community, economy and environment is therefore ongoing event must have a concept of growth on the environment and social and tourism.

\section{n) Increased Investment in Bandung}

(Chalkley and Essex, 1999) said that if the Mega Event to get billions of dollars of investment from the distribution infrastructure renovation and environmental advocates to ensure Mega Event was very effective.

o) Increased of state tax

(Taylor and Gratton, 1988; Coopers and Lybrand, 1989; Turco, 1995; Andersson and Samuelson, 2000) The impact of the event clearly demonstrated the benefits of the increase in taxes to all levels of government and the main reason of travel and tourism resulted in more consumption of goods and services is very clear taxed, as well as bring in new tourism revenue.

\section{p) Improved Living Conditions Community}

Soutar and Mcleod (1993) examined public perceptions of the American Cup. In the event economic impact and congestion. And it was discovered that resulted in the impact on the living conditions of the host city. In accordance with the government of Bandung that improve people's living conditions by building infrastructure and developing economic conditions through product - flagship creative product.

\section{q) Development of Relative Industry}

According to (GLA, 2004) in a report carnival has a significant impact to the local economy as it developed is an art, clothing, car rental, hotel and catering, tour, advertising and transportation.

\section{r) Returns, Preservation, Protection of Historic Buildings}

In study of documentation in the form of articles via the internet and social media such as nasional.tempo.co article number seven, satuharaoan.com, antaranews.com, sp.beritasatu.com, republika.co.id, bandungekspres.co.id, cikalnews.com say that did occur preservation of historic buildings at the time of preparation of KAA assisted by the community volounteer and temporary workers as well as from the government itself that the addition Soekarno statue in the historic building, painting historic buildings and cleanliness more attention around the building.

\section{s) Preservation of Local Culture}

Cooper in the implementation of major activities would have to obtain funds obtained from various event activities, fund is also piped to the preservation of local cultural activities to a country which is used as host

\section{t) Conservation of Natural Resources}

In documentary study of online media there is much, 9 arikel of media as follows kompasiana.com, galamedianews.com, microsite.metrotvnews.com, balebandung.com, galamedianews.com, jurnalbandung and jabar.metrotvnews.com, hu-pakuan.com and kompasiana.com who said many acts of cleaning the river the river Cikapundung by the janitor and was helped by volounteer community and local youth clubs to continue until now, but it made Cikapundung park. 
TABEL 1 LOCAL RESIDENT PERCEPTION OF POSITIVE AND NEGATIVE IMPACT AACC

\section{Indicators}

\section{Intervewee}

Positive Negative Doubt

\section{Positive impact}

Opportunity to introduce Bandung To The World

Improved image of Bandung in the International Scope

Increased presence of Bandung, in the international arena

Increase of Bandungs' Residents Cohesion

Improving Bandungs' Citizens Pride

Occurs community spirit

Improved City Beautification

Improved Shopping Facilities

Increased Recreation Facilities

Improved sanitation facilities

Improvement of Tourism Service Facilities

Development Acceleration of State Infrastructure

Increasing Employment Opportunities

Improvements Economic Conditions

Growth Acceleration Bandung

Increased Investment in Bandung

Increased of state tax

Improved Living Conditions Community

Development of Relative Industry

Returns, Preservation, Protection of Historic Buildings

Preservation of Local Culture

Conservation of Natural Resources

\section{Negative Impact}

Disturbance by visitors

Increased Traffic Problems

Increased levels of crime

Improvement Alcoholism, Prostitution

Environmental Damage Nature and Landscape

Destruction of local ecosystems

Improvement of Environmental Pollution (Waste, Water, Air and Noise)

Cultural conflict

Influence of Lifestyle Local Residents In Local Culture Development Creating Negative Impact
30

$\begin{array}{lll}30 & 8 & - \\ 36 & 2 & -\end{array}$


Negative impact Discussion

a) Disturbance by visitors

Study the documentation I have found there are five articles of galamedia.news.com, detik.com, bandungnewsphoto.com and some of tribbunnews.com who said that the buildup of visitors on the night of the party of the people KAA implemented, but it does not reduce the density of the community's spirit came the Asian African sub Parade and other events KAA.

b) Increased Traffic Problems

Sherwood: 2007 that there will be effects on the environment and social life in terms of interference in people's lifestyle activities refers to the increase in traffic and noise and the daily routine - a normal day because there is the festival activities in an area that hosts an activity.

c) Increased levels of crime

Donald Getz: 2007 that crime on a large activities such as Festival will obviously occur diakrenakan Festival is driving people to bring more money to be issued at the Festival and bringing tools - a documentation tool that could potentially provoke the crime occurred

d) Improvement Alcoholism, Prostitution

According Gursoy, Kim, \& Uysal; Kim, Gursoy, \& Lee; Kim \& Petrick; Ohmann, Jones, \& Wilkes said that the sides of the expected benefits to the implementation of a Mega Event creates a negative effect one other than such as environmental damage, excessive spending, security problems, traffic congestion and population displacement, prostitution is a negative impact diresahkan occurs when AACC because these activities invite the heads of state who have the western and eastern cultures.

e) Environmental Damage Nature and Landscape

Gursoy, Kim, \& Uysal; Kim, Gursoy, \& Lee; Kim \& Petrick; Ohmann, Jones, \& Wilkes said that the damage to the landscape is the negative effect that in tumbulkan for their implementation Festival.

f) Improvement of Environmental Pollution (Waste, Water, Air and Noise)

Gets that what the public were present to suata big events can lead to the destruction of nature, landscape, pollution and also the addition of pollution associated with the state of the indicators of an increase in environmental pollution in the Asian African Conference Commemoration is a lot of waste garbage generated from the visitors who come and recognized by the local community but from the fact that garbage can be resolved after a day of activities completed

g) Cultural conflict

Gursoy, Kim, \& Uysal; Kim, Gursoy, \& Lee; Kim \& Petrick; Ohmann, Jones, \& Wilkes said that the damage to the landscape is the negative effect that in tumbulkan for Reviews their implementation Festival

\section{5) Special Market}

This recommendation is to minimize the negative impact of the increase in the cost of living indicators. Advised the government and organizers work together to make policy on h) Influence of Lifestyle Local Residents In Local Culture Development Creating Negative Impact

Hiller (1995) on the negative side, mega events can be a nuisance to the lifestyle of the locals, when the city held a big event and visitors come, where visitors require special attention so that no negative side that visitors such as vandalizing public property after the implementation of the Conference Asia Africa. Visitors who come berselfie and climbed onto a chair that cause fractures and broken chairs. Evidenced in several media articles about the destruction of the chair Garden due visitors selfie on the chair.

\section{RECOMMENDATION}

1) "Increasing Beautyfication City"

It is recommended that the government and the organizers work together, so that happens equalization AACC region for the implementation of the next event. It would be better if the sub-sub event was added and held in different areas with a large scale.organize the topics on a relational, hierarchical basis. For example, the paper title is the primary text head because all subsequent material relates and elaborates on this one topic.

2) Smart Bazzar

It is advisable for the government and the organizers work together so that there is equal distribution of the region's Food Bazzar, and are held on a regular basis. Can be carried out on Sunday because it is the holidays and weekends. With the food bazaar also provides an opportunity Bandung SMEs and local communities to improve the products featured in Bandung.

\section{3) Big Opportunity}

Government and party organizer would have been better if it makes jobs as volunteers AACC not only through the website, but rather socialized to local people through youth. Increasing the involvement of youth is important to support local communities in each region dimasing- obtain information regarding the event Bandung. Then not only the work that is volunteer only in infrastructure but also may be involved. If the engagement is executed properly, this KAA will directly impact the community in the form of changes in the living conditions of local duo especially in improving economic conditions.

4) Local Creative Product Exhibition

Suggested the government make large-scale exhibition program that aims to promote local products. Given a local exhibition will attract a lot of media coverage and in other words the participants of the exhibition is a local product developers will benefit from another form of mass promotion and can have an impact on their income. Exhibition of local products is exempted in the area around Bandung region as an example of dividing the area into 4 Bandung, Bandung north, south, east and west, as well as in those who have a superior product and be able to compete nationally or internationally.

Special Line Market so that when the next event KAA market remains in operation. Given this market is still needed by the local society in memenugi daily needs today. There should be no closure. Due to the closing of the market will make the daily needs - for example the 
vegetables and the other to be expensive. Therefore to anticipate them, they invented a special line ranging from access to get there and order in the region that will be the current market AACC.

6) Green Event

This recommendation is to minimize the negative impacts of the indicators of sustainability of natural resources, the destruction of nature and lanskape, the destruction of local ecosystems, the increase in environmental pollution.

It is recommended that the Government make policy or guidelines regarding the Sustainable Event for the city of Bandung. Sustainable is meant here is to begin to multiply event that has dimensions of Eco-Tourism from planning, of implementation of, and even post event. If the event is held again invited many guests from other countries should this city should start beralihmenggunakan system Green Hotels, Green Venue, Green Vendors. In addition to the construction of public open space facilities would be better if it can be enjoyed by the people. Here are examples of sustainable events from EPA guidelines Division, Events Tasmania. These Guidelines are excellent for organizers and government guidelines in considering the negative impact of an event. These Guidelines serve to keep the preservation of natural resources and minimize the environmental damage and the destruction of local ecosystems Bandung.

\section{REFERENCES}

[1] Arikunto, S, Metodologi Penelitian. Penerbit PT. Rineka Cipta. Jakarta, 2002.

[2] Arikunto, S, Prosedur Penelitian Suatu Pendekatan Praktek. Jakarta, PT.Rineka Cipta, 2010.
[3] Balduck, A, Marc, M, \& Marc, B The Social Impact of the Tour de France: Comparisons of Residents' Pre- and Post- event Perceptions. European Sport Management Quarterly, Vol. 11, No. 2, pp. 91-113.

[4] Yong, Zhou. 2010. Resident Perceptions Toward the Impacts of the Macao Grand Prix. Journal of Convention \& Event Tourism, Vol. 11, pp.138-153.

[5] Yeqiang Lin (2000). A Critical Review of Social Impacts of MegaEvents

[6] Swart, Kamilla, \& Megan C.J. 2012. Informal residents' perceptions of the 2010 FIFA World Cup: A case study of an informal settlement in Cape Town. African Journal for Physical, Health Education, Recreation and Dance, Vol. 1 pp. 42-52.

[7] ShangChun, Ma, ShangMin, Ma, \& Ian, D.R. 2012. Host Residents' Perception of The Impact of the 2009 World Games on Kaohsiung: a Longitudinal Perspective. South African Journal for Research in Sport, Physical Education and Recreation, Vol. 34, no. 2, pp. 115-135.

[8] Sandy, Chen. 2011. Residents' Perceptions of the Impact of Major Annual Tourism Events in Macao: Cluster Analysis. Journal of Convention \& Event Tourism, Vol. 12 pp. 106-128.

[9] Ritchie, B.W, Richard, S, \& Bethany C. 2009. Resident Perceptions of Mega-Sporting Events: A Non-Host City Perspective of the 2012 London Olympic Games. Journal of Sport \& Tourism, Vol. 14, No. 2-3, pp. 143-167.

[10] Raj Razaq and James Musgrave (2006). Event Management and Sustainability. London: CABI North American.

[11] Preuss, H, \& Harry, Solberg. 2006. Attracting Major Sporting Events: The Role of Local Resident. European Sport Management Quarterly, Vol. 6, No. 4, pp. 391-411.

[12] Ntloko, N.J, \& Kamilla, Swart. 2008. Sport Tourism Event Impact on The Host Communit: a Case Study of Red Bull Big Wave Africa. South African Journal for Research in Sport, Vol. 30, No. 2, pp. 79-93.

[13] Jie, Yang, Xuehui, Z, \& Yingkang, G. 2010. Local Residents' Perceptions of the Impact of 2010 Expo. Journal of Convention \& Event Tourism, Vol. 11, pp. 161-175.

[14] Herman, P.U, Liezel, D.U.P, Willie J.L.C, \& Susan, G. 2013. Local Residents' Perception of The 2010 FIFA World Cup ${ }^{\mathrm{TM}}$. South African Journal for Research in Sport, Vol. 35, No. 1, pp. 25-37.

[15] Getz, Donald. 2005. Event Management and Event Tourism. New York: Cognizant Communication Coorporation.

[16] Getz, Donald (2007). Event Studies: Theory, research and policy for planned events. Oxford: Butterworth-Heinemann.

[17] Balduck, A, Marc, M, \& Marc, B. 2011. The Social Impact of the Tour de France: Comparisons of Residents' Pre- and Post- event Perceptions. European Sport Management Quarterly, Vol. 11, No. 2, pp. 91113.

[18] FayosSola, Eduardo. 1997. The Impact of Mega Events. World Tourism Organizati, Capitan Haya 42, 28020, Spain.

[19] Canterbury Residents in Relation to the Tour de France 2007. Journal of Sport \& Tourism, Vol. 12, no. 4, pp. 229-248. 